\title{
PENGARUH TINDAKAN SUPERVISI DAN PELATIHAN AUDITOR TERHADAP PROFESIONALISME AUDITOR PEMULA (STUDI EMPIRIS PADA KAP DI WILAYAH JAKARTA PUSAT)
}

\author{
Anita Mayangsari \\ Nia Tresnawaty, SE.,M.Ak \\ Program Studi Akuntansi Fakultas Ekonomi Universitas Satya Negara Indonesia
}

\begin{abstract}
ABSTRAK
Penelitian ini diharapkan dapat memberikan kontribusi pada pengembangan ilmu pengetahuan di bidang auditing dan dapat digunakan sebagai referensi dan pembanding atau dasar penelitian lebih lanjut berkaitan dan tema penelitian ini. Bagi auditor yang bekerja di Kantor Akuntan Publik (KAP), hasil penelitian ini diharapkan dapat memberikan informasi mengenai pengaruh tindakan supervisi dan pelatihan auditor terhadap profesionalisme auditor pemula sehingga dapat menjadi bahan evaluasi dan masukan bagi auditor dalam melaksanakan praktik

Penelitian ini menggunakan tindakan supervisi dan pelatihan auditor sebagai variabel independen dan profesioanlisme sebagai variabel dependen, karena auditor pemula penting memiliki tingkat pemahaman yang tinggi atas tindakan supervisi dan pelatihan auditor dalam melaksanakan tugasnya, sehingga profesionalisme auditor tersebut diharapkan menjadi lebih baik.

Populasi penelitian ini adalah seluruh auditor yang bekerja di KAP, yang tersebar di wilayah Jakarta Pusat yang tercatat di Direcotory Ikatan Akuntan Publik (IAI) Kopatermen Akuntan Publik 2013. Sampel penilitian ini yaitu 50 auditor junior yang terdapat di 14 KAP. Teknik pengambilan sampel menggunakan metode Purposive Sampling yaitu pengambilan sampel berdasarkan pertimbangan (judgement sampling) tertentu yang ditetapkan peneliti yaitu auditor pemula yang pernah mealkukan pekerjaan di bidang auditing, hal ini dilakukan karena auditor tersebut telah beradaptasi dengan lingkungan kerjanya, sehingga auditor dapat memahani bahwa tindakan supervisi dan pelatihan auditor merupakan factor utama untuk menunjang tingkat profesioanlisme.

Pengujian instrument penelitian meliputi uji realibilitas, uji validitas dan uji asumsi klasik, sedangkan analisa data penelitian menggunakan uji t, uji F, regresi linier berganda, dan uji koefisien determinasi $\left(\mathrm{r}^{2}\right)$.

Hasil penelitian menunjukkan 1) tindakan supervisi berpengaruh positif terhadap profesionalisme auditor pemula, 2) pelatihan auditor berpengaruh positif terhadap profesionalisme auditor pemula, 3) tindakan supervisi dan pelatihan auditor secara bersama-sama berpengaruh positf terhadap profesionalisme auditor pemula
\end{abstract}

Kata Kunci: Tindakan Supervisi, Pelatihan Auditor, Profesionalisme Auditor Pemula 


\section{PENDAHULUAN}

Pengungkapan pelaporan keuangan dalam tahun-tahun belakangan ini semakin berkembang, seiring dengan perkembangan dunia usaha yang semakin meningkat pula. Pengungkapan pelaporan keuangan perusahaan membutuhkan pengungkapan atas kondisi perusahaan yang sebenarnya. Oleh sebab itu, kebutuhan jasa akuntan publik dari waktu ke waktu semakin meningkat. Peran seorang auditor sangat dibutuhkan dalam hal ini, baik senior maupun pemula. Dalam melaksanakan tugasnya, seorang auditor juga di tuntut untuk memiliki profesionalisme yang tinggi. Profesionalisme auditor merupakan cerminan seberapa jauh seorang auditor dapat mengaplikasikan etika profesi yang harus dijalankan. Selain itu, juga tercermin pada penerapan berbagai keterampilan dan skill yang optimal dalam menjalankan tugas-tugasnya. Auditor yang profesional dapat meyakinkan publik sehingga audit yang dihasilkan lebih berkualitas.

Berdasarkan berbagai studi, AECC (Accounting Education Change Comission), sebagai badan yang dibentuk untuk menangani pendidikan akuntan dalam upaya mempertahankan profesi akuntan sebagai pilihan karir yang menarik di Amerika Serikat, menerbitkan Issue Statement No.4. Salah satu isi dari Issue Statement No. 4 adalah AECC Recommendations Early Work Experience adalah sejumlah rekomendasi AECC kepada supervisor akuntan pemula untuk melaksanakan supervisi dengan tepat khususnya dalam tiga aspek utama tindakan supervisi sebagaimana yang disarankan oleh AECC.

Ketiga aspek tindakan supervisi yang dimaksud adalah supervisor hendaknya menunjukkan sikap kepemimpinan dan mentoring yang kuat, supervisor hendaknya menciptakan kondisi kerja yang mendorong tercapainya kesuksesan, dan supervisor hendaknya memberikan penugasan yang menantang dan menstimulasi terselesaikannya tugas.

Untuk memenuhi persyaratan sebagai professional, auditor harus melalui pelatihan teknis khusus. Pelatihan ini harus mencakup aspek teknis maupun pendidikan umum. Selanjutnya dalam Pernyataan Standar Auditing (PSA) No.4 tahun 2001 menyatakan bahwa yang dimaksud dengan pelatihan seorang professional mencakup pula kesadarannya yang terus-menerus terhadap perkembangan yang terjadi dalam bisnis dan profesi. Pelatihan tersebut dapat berupa kegiatan-kegiatan sepperti seminar, symposium, lokakarya pelatihan itu sendiri, dan kegiatan penunjang keterampilan lainnya yang berkaitan dengan pengetahuan mengenai kekeliruan. Para auditor juga mengalami proses sosialisasi agar dapat menyesuaikan diri dengan perubahan situasi yang akan ditemui melalui program pelatihan ini.

Dengan adanya tindakan supervisi untuk selalu mengontrol, membimbing, mengawasi, dan mengevaluasi kinerja auditor pemula serta pelatihan audit yang cukup maka diharapkan profesionalisme dari seorang auditor pemula tersebut dapat tumbuh seiring dengan pengalaman yang terus bertambah dari waktu ke waktu.

Berdasarkan latar belakang di atas, maka peneliti tertarik untuk melakukan penelitian dengan judul,"Pengaruh Tindakan Supervisi dan Pelatihan Auditor Terhadap Profesionalisme Auditor Pemula.” 


\section{Perumusan Masalah}

Berdasarkan latar belakang penel;itian tersebut di atas, maka rumusan masalah penelitian ini adalah sebagai berikut:

1. Apakah tindakan supervisi berpengaruh terhadap profesionalisme auditor pemula

2. Apakah pelatihan auditor berpengaruh terhadap profesionalisme auditor pemula

\section{Tujuan Penelitian}

1. Untuk mengetahui apakah tindakan supervisi berpengaruh terhadap profesionalisme auditor pemula

2. Untuk mengetahui apakah pelatihan auditor berpengaruh terhadap profesionalisme auditor pemula

\section{Manfaat Penelitian}

Hasil penelitian ini diharapkan dapat memberikan kontribusi pada pengembangan ilmu pengetahuan di bidang auditing dan dapat digunakan sebagai referensi dan pembanding atau dasar penelitian lebih lanjut berkaitan dan tema penelitian ini. Bagi auditor yang bekerja di Kantor Akuntan Publik (KAP), hasil penelitian ini diharapkan dapat memberikan informasi mengenai pengaruh tindakan supervisi dan pelatihan auditor terhadap profesionalisme auditor pemula sehingga dapat menjadi bahan evaluasi dan masukan bagi auditor dalam melaksanakan praktik

\section{LANDASAN TEORI}

\section{Tindakan Supervisi}

Supervisi mencakup pengarahan usaha asisten dalam mencapai tujuan audit dan penentuan tujuan tersebut tercapai. Unsur supervisi adalah memberikan instruksi kepada asisten, tetap menjaga penyampaian informasi, masalah-masalah penting yang dijumpai dalam mengaudit, mereview pekerjaan yang dilaksanakan dan menyelesaikan perbedaan pendapat staf audit kantor akuntan (SPAP:2001)

Untuk menjadi seorang auditor pemula yang profesional, tindakan supervisi dan pelatihan auditor sangat diperlukan. Hal ini diatur dalam PSA No.5 tahun 2011 (SA Seksi 311: 311.1) yang mengharuskan bahwa, "Pekerjaan harus direncanakan sebaikbaiknya dan jika digunakan asisten harus disupervisi dengan semestinya".

\section{Pelatihan Auditor}

Menurut Andrew F. Sikula dalam Anwar (2011:44) Pelatihan adalah "Suatu proses pendidikan jangka pendek yang mempergunakan prosedur sistematis dan terorganisir dimana pegawai non-manajerial mempelajari pengetahuan dan keterampilan teknis dalam tujuan terbatas." Selanjutnya Edwin B. Flippo dalam Malayu (2006:70) menyatakan bahwa "pelatihan adalah merupakan suatu usaha peningkatan 
pengetahuan dan keahlian seorang karyawan untuk mengerjakan suatu pekerjaan tertentu."

Untuk memenuhi persyaratan sebagai seorang profesional, auditor harus melalui pelatihan teknis maupun pendidikan umum yang cukup. Asisten pemula yang baru masuk ke dalam karir auditor harus memperoleh pengalaman profesionalnya dengan supervisor yang memadai dan review kerja atas pekerjaannya dari atasan yang lebih berpengalaman.

Dalam Pernyataan Standar Auditing (PSA) No.04 tahun 2001 (SA Seksi 210; 210.1) disebutkan bahwa standar umum yang pertama adalah audit harus dilaksanakan oleh seseorang atau lebih yang memiliki keahlian dan pelatihan teknis. Selanjutnya dalam PSA tersebut dikatakan bahwa dalam melaksanakan audit untuk sampai pada pernyataan pendapat, auditor senantiasa bertindak sebagai seorang ahli dalam bidang akuntansi dan bidang auditing. Pencapaian keahlian tersebut dimulai dengan pendidikan formal auditor diperluas dengan pengalaman selanjutnya dalam praktek audit.

Pelatihan dapat berupa kegiatan-kegiatan, seperti seminar, symposium, lokakarya pelatihan itu sendiri dan kegiatan penunjang keterampilan lainnya. Program pelatihan mempunyai pengaruh yang besar dalam peningkatan keahlian auditor, khususnya auditor junior. Auditor yang baru bekerja belum memahami secara benar bagaimana melakukan pekerjaan dalam penugasan audit sehingga dengan pelatihan audit junior dapat meningkatkan pengetahuan, kemampuan kerja serta memperbaiki prestasi kerja pada pekerjaan yang menjadi tanggung jawabnya.

\section{Profesionalisme Auditor}

Profesionalisme auditor diatur di dalam PSA No. 4, SPAP (2001:230.1) menyatakan bahwa "Dalam pelaksanaan audit dan penyusunan laporannya, auditor wajib menggunakan kemahiran profesionalnya dengan cermat dan seksama." Standar ini menuntut auditor independen untuk merencanakan dan melaksanakan pekerjaannya dengan menggunakan kemahiran profesionalismenya secara cermat dan seksama.Penggunaan kemahiran profesional dengan kecermatan dan keseksamaan menekankan tanggung jawab setiap profesional yang bekerja dalam organisasi auditor independen untuk mengamati standar pekerjaan lapangan dan standar pelaporan. Penggunaan kemahiran profesional dengan cermat dan seksama menyangkut apa yang dikerjakan auditor dan bagaimana kesempurnaan pekerjaannya tersebut.

Konsep profesionalisme yang dikembangkan oleh Hall (1968) dalam Novanda Friska (2012:15) banyak digunakan oleh para peneliti untuk mengukur profesionalisme dari profesi auditor yang tercermin dari sikap dan perilaku. Menurut Hall (1968) dalam Novanda Friska (2012:15) terdapat lima dimensi profesionalisme, yaitu:

\section{a. Pengabdian pada profesi}

Pengabdian pada profesi dicerminkan dari dedikasi profesionalisme dengan menggunakan pengetahuan dan kecakapan yang dimiliki. Keteguhan untuk tetap melaksanakan pekerjaan meskipun imbalan ekstrinsik kurang. Sikap ini adalah 
ekspresi dari pencurahan diri yang total terhadap pekerjaan. Pekerjaan didefinisikan sebagai tujuan, bukan hanya alat untuk mencapai tujuan. Totalitas ini sudah menjadi komitmen pribadi, sehingga kompensasi utama yang diharapkan dari pekerjaan adalah kepuasan rohani, baru kemudian materi.

\section{b. Kewajiban sosial}

Kewajiban sosial adalah pandangan tentang pentingnya peranan profesi dan manfaat yang diperoleh baik masyarakat maupun profesional karena adanya pekerjaan tersebut.

\section{c. Kemandirian}

Kemandirian dimaksudkan sebagai suatu pandangan seseorang yang profesional harus mampu membuat keputusan sendiri tanpa tekanan dari pihak lain (pemerintah, klien, dan bukan anggota profesi).Setiap ada campur tangan dari luar dianggap sebagai hambatan kemandirian secara profesional.

\section{d. Keyakinan terhadap peraturan profesi}

Keyakinan terhadap profesi adalah suatu keyakinan bahwa yang paling berwenang menilai pekerjaan profesional adalah rekan sesama profesi, bukan orang luar yang tidak mempunyai kompetensi dalam bidang ilmu dan pekerjaan mereka.

\section{e. Hubungan dengan sesama profesi}

Hubungan dengan sesama profesi adalah menggunakan ikatan profesi sebagai acuan, termasuk didalamnya organisasi formal dan kelompok kolega informal sebagai ide utama dalam pekerjaan.Melalui ikatan profesi ini para profesional membangun kesadaran profesional.

\section{METODE PENELITIAN}

\section{Tempat dan Waktu Penelitian}

Penelitian ini dilakukan di Kantor Akuntan Publik yang berada di daerah Jakarta Pusat. Waktu penelitian ini dilakukan sekitar 3 bulan yaitu sejak bulan April 2014 sampai Juli 2014.

\section{Desain Penelitian}

Desain penelitian yang digunakan adalah Penelitian Kausal (Causal Research) yang merupakan metode penelitian untuk mengidentifikasi hubungan sebab-akibat. Penelitian kausal digunakan untuk mengetahui pengaruh antara satu atau lebih variabel bebas (Independent Variable) terhadap variabel terikat (Dependent Variable).

\section{Populasi dan Sampel}

Populasi penelitian ini adalah semua auditor yang bekerja di Kantor Akuntan Publik di wilayah JakartaPusat. Sedangkan teknik untuk pengambilan sampel ditentukan dengan metode Purposive Sampling, dengan kriteria yang digunakan berdasarkan pertimbangan (judgement) tertentu yang ditetapkan peneliti yaitu auditor yang pernah melaksanakan pekerjaan di bidang auditing. Penentuan jumlah sampel menurut menurut Gay dalam Sri Yuliawati (2009), disarankan menggunakan sampel 
minimal sebanyak 30 responden apabila jenis penelitian berupa penelitian koresional dan studi kausal koparatif. Berhubung jenis dan desain penelitian ini adalah penelitian kausal (Causal Research), maka penilitian ini dirancanakan menggunakan 75 auditor di Kantor Akuntan Publik yang berada di daerah Jakarta Pusat

\section{Operasional Variabel Penelitian}

Variabel merupakan segala sesuatu yang akan menjadi objek pengamatan dalam penelitian. Dalam penelitian ini peneliti menggunakan variabel bebas (Independent Variable) dan variabel terikat (Dependent Variable). Variabel bebas (Independent Variable) yaitu variabel yang mempengaruhi atau yang menjadi sebab perubahannya/timbulnya variabel dependen (terikat) terdiri dari . Dalam penelitian ini yang menjadi variabel bebas (Independent Variable) adalah tindakan supervisi dan pelatihan auditor. Variabel Terikat (Dependent Variable) merupakan variabel yang dipengaruhi atau yang menjadi akibat karena adanya variabel bebas. Dalam penelitian ini yang menjadi variabel Y adalah Profesionalisme Auditor Pemula.

Berdasarkan kajian pustaka, pendekatan operasional variabel untuk masingmasing variabel dalam pemnelitian ini adalah sebagai berikut:

1. Tindakan Supervisi adalah tindakan mengawasi dan mengarahkan penyelesaian pekerjaan. Instrumen yang digunakan adalah rincian saran-saran supervisi yang terdiri dari sikap kepemimpinan dan mentoring, kondisi kerja, dan penugasan, dimana dari rincian saran-saran tersebut dapat dijabarkan lebih lanjut dalam kuesioner nantinya.

2. Pelatihan auditor adalah kegiatan untuk memperbaiki prestasi baik formal atau informal untuk meningkatkan keahlian dan kemampuan teknis auditor. Instrument penelitian yang digunakan dalam penelitian ini meliputi pendidikan formal, pengalaman-pengalaman selanjutnya dalam praktik audit, kesadarannya yang terus menerus terhadap perkembangan yang terjadi dalam bisnis dan profesi, mempelajari dan memahami serta menerapkan ketentuan-ketentuan baru dalam prinsip akuntansi dan standar auditing yang ditetapkan.

3. Profesionalisme Auditor Pemula adalah sikap atau semangat mempertahankan status profesi dan memelihara citra publik terhadapnya, bertanggungjawab terhadap diri sendiri maupun ketentuan hukum dan peraturan masyarakat, menekuni ilmu dan pekerjaan dalam bidang tersebut serta dipengaruhi oleh faktorfaktor pengabdian pada profesi, kewajiban sosial, kemandirian, keyakinan terhadap profesi, hubungan dengan sesama profesi.

\section{Jenis Data}


Dalam penelitian ini peneliti menggunakan data primer untuk mengukur variabel independen dan variabel dependen yang diambil dari individu atau perseorangan yaitu hasil pengisian kuesioner.

\section{Teknik Pengumpulan Data}

Teknik pengumpulan data dilakukan dengan cara menyebarkan kuesioner yang berisi daftar pernyataan kepada responden yang akan disebarkan untuk semua auditor yang bekerja di Kantor Akuntan Publik yang dilakukan penelitian. Skala yang digunakan adalah skala likert lima poin dengan rentang angka 1-5 yang memberikan gambaran sampai seberapa jauh responden melaksanakan fungsi sesuai dengan pernyataan yang diberikan. Skala likert digunakan untuk mengukur sikap, pendapat, dan persepsi seseorang atau sekelompok orang tentang gejala sosial.

Dengan menggunakan skala likert, maka variabel yang akan diukur dijabarkan menjadi dimensi, dimensi menjadi sub variabel kemudian sub variabel dijabarkan menjadi indikator-indikator yang dapat diukur. Akhirnya indikator-indikator yang terukur ini dapat dijadikan titik tolak untuk membuat item instrumen yang berupa pernyataan yang perlu dijawab oleh responden. Setiap jawaban dihubungkan dengan bentuk pernyataan yang diungkapkan dengan kata-kata: 1 = Sangat Tidak Setuju (STS), 2 = Tidak Setuju (TS), 3 = Kurang Setuju (KS), 4 = Setuju (S), dan 5 = Sangat Setuju (SS)

\section{HASIL PENELITIAN}

\section{Hasil Pengolahan Data}

\section{Pengumpulan Data}

Penelitian ini dilaksanakan dengan menyebarkan 75 kuesioner di Kantor Akuntan Publik di Jakarta Pusat dengan tingkat pengembalian 65\%. Hal ini berarti bahwa kuesioner yang disebar, 50 kuesioner yang berhasil dikumpulkan dan pengisian lengkap. Kuesioner ini didistribusikan di KAP Jakarta Pusat sebanyak 14 KAP.

\section{Pengujian Instrument Penelitian}

\section{Uji Reliabilitas}

Uji reliabilitas adalah alat untuk mengukur suatu kuesioner yang merupakan indikator dari variabel. Suatu kuesioner dikatakan reliabel atau handal jika jawaban seseorang terhadap pernyataan tersebut konsisten atau stabil dari waktu ke waktu. Untuk mengukur reliabilitas digunakan uji statistik Cronbach Alpha ( $\alpha$ ). Suatu variabel dikatakan reliabel jika memberikan nilai Cronbach Alpha> 0,60. Sedangkan jika sebaliknya data tersebut dikatakan tidak reliabel (Imam Ghozali, 2005:41-42)

Hasil pengujian reliabilitas nilai Cronbach Alpha tindakan supervisi menunjukkan nilai $0,937>0,60$, pelatihan auditor menujukkan nilai $0,885>0,60$, dan profesionalisme auditor pemula memiliki nilai $0,903>0,6$. Ini menunjukkan bahwa item-item pertanyaan reliabel. 


\section{Uji Validitas}

Validitas yaitu sejauh mana ketepatan dan kecermatan suatu alat ukur dalam melakukan fungsi ukurnya. Validitas digunakan untuk mengetahui kesamaan antara data yang terkumpul dengan data yang sesungguhnya terjadi pada proyek yang diteliti, sehingga dapat diperoleh data yang valid. Pada program SPSS teknik pengujian yang sering digunakan dalam penelitian untuk uji validitas adalah menggunakan korelasi Bivariate Pearson (Pearson Product Moment) dan Corrected Item-Total Correlation (Joko Sulistyo, 2002:40). Ketentuan jika nilai $r_{\text {hitung }}>$ nilai $r_{\text {tabel }}$ maka item pernyataan dinyatakan valid. Hasil uji validitas varibel tindakan supervisi antara 0,651-0,896 > r tabel 0,282; pelatihan auditor skor antara 0,658-0,772 > r tabel 0,282; dan profesionalisme auditor pemula dengan skor antara 0,313-0,795 > r tabel 0,282, maka dapat disimpulkan bahwa semua variabel valid dengan signifikan pada level 0,01.

\section{Uji Normalitas}

Uji normalitas dimaksudkan untuk memperlihatkan bahwa sampel diambil dari populasi yang berdistribusi normal (Joko Sulistyo, 2002:50). Normalitas dapat diketahui dengan melihat tabel One-Sample Kolmogorov - Smirnov Test pada kolom Asymp Sig (2-tailed) yaitu jika p value (sig) > 0.05 maka dapat disimpulkan bahwa data yang diambil dari populasi terdistribusi normal

Dari hasil pengujian normalitas terlihat signifikan tindakan supervisi adalah 0,064 , taraf signifikan pelatihan auditor adalah 0,086, sedangkan profesionalisme auditor pemula sebesar 0,060. Angka-angka tersebut lebih besar dari 0,05 sehingga dapat diartikan bahwa data-data tersebut berdistribusi normal.

\section{Uji Multikolinieritas}

Uji multikolinieritas bertujuan untuk menguji apakah pada model regresi ditemukan adanya korelasi antar variabel bebas (independen). Model regresi yang baik seharusnya tidak terjadi korelasi diantara variabel bebasnya. Uji multikolinieritas dalam SPSS dilakukan dengan uji regresi, dengan nilai patokan VIF (Variance Inflation Factor) dan koefisien korelasi antarvariabel bebas (Joko Sulistyo 2002:56). Untuk menguji multikolinieritas dapat dilihat dari nilai tolerance dan nilai VIF. (Variance Inflation Factor). Berdasarkan nilai tolerance, nilai yang terbentuk harus di atas $10 \%$ dan bila menggunakan VIF, nilai yang terbentuk harus kurang dari 10, bila tidak maka akan terjadi multikolinieritas dan model regresi tidak layak untuk digunakan. Hasil penelitian menunjukkan bahwa nilai variance inflation factor (VIF) kedua variabel tindakan supervisi dan pelatihan auditor adalah lebih kecil dari 10, dan nilai tolerance diatas $10 \%$ sehingga dapat disimpulkan bahwa antar variabel independen tidak terjadi masalah multikolinearitas

\section{Uji Heterokedastisitas}

Uji heterokedastisitas terjadi jika varian dari residual suatu pengamatan ke pengamatan lain terjadi ketidaksamaan. Model regresi yang baik adalah tidak terjadi 
heterokedastisitas. Untuk mendeteksi heterokedastisitas dapat melihat grafik scatterplot yaitu dengan melihat ada tidaknya pola tertentu pada grafik dimana sumbu $\mathrm{X}$ dan $\mathrm{Y}$ yang telah diprediksi dan sumbu $\mathrm{Y}$ adalah residual yang telah di studendized. Dasar pengambilan kesimpulan adalah jika terdapat pola tertentu seperti titik yang ada membentuk suatu pola tertentu yang teratur maka telah terjadi heterokedastisitas sebaliknya jika tidak terbentuk pola yang jelas dan titik-titik menyebar di atas dan di bawah angka 0 pada sumbu Y maka tidak terjadi heterokedastisita.

Pada grafik plot antara nilai prediksi variabel terikat (Zpred) dan variabel residual (Zresid) tidak ada pola yang jelas serta titik-titik menyebar di atas dan di bawah angka pada sumbu Y maka dapat disimpulkan tidak terjadi heterokedastisitas

Scatterplot

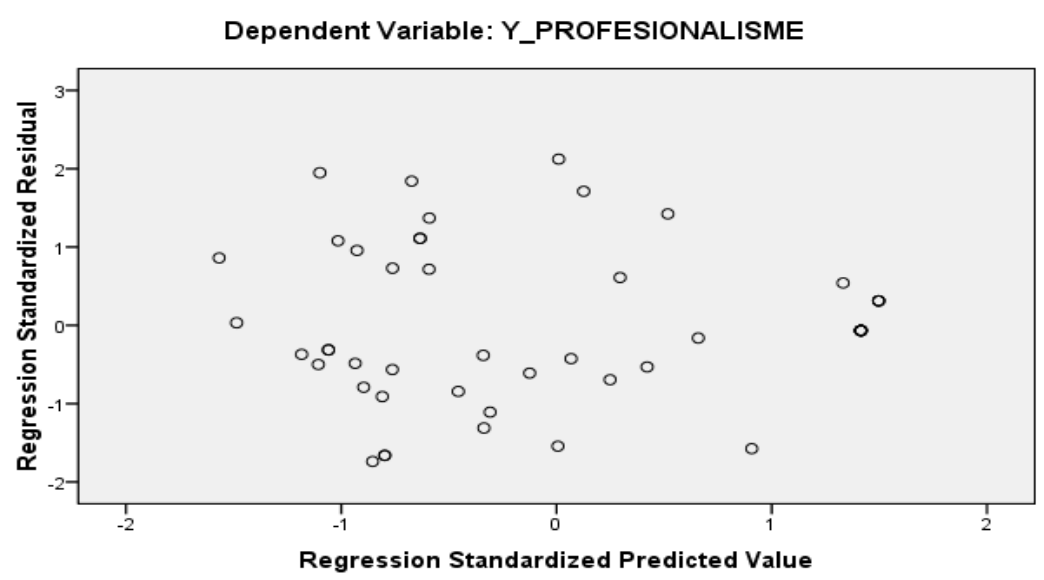

\section{Uji Auto Korelasi}

Autokorelasi merupakan korelasi antara anggota observasi yang disusun menurut waktu atau tempat. Model regresi yang baik seharusnya tidak terjadi autokorelasi. Metode pengujian yang sering digunakan adalah dengan uji Durbin-Watson (uji DW) dengan ketentuan:

1. Jika DW lebih kecil dari dL atau lebih besar dari (4-dL) maka hipotesis nol ditolak, yang berarti terdapat autokorelasi.

2. Jika DW terletak antara dU dan (4-dU), maka hipotesis nol diterima, yang berarti tidak ada autokorelasi.

3. Jika DW terletak antara dL dan dU atau diantara (4-dU) dan (4-dL), maka tidak menghasilkan kesimpulan yang pasti.

Durbin Watson output SPSS, tingkat signifikansi 0.05 dan jumlah data $(\mathrm{n})=50$, serta $\mathrm{k}=2$ ( $\mathrm{k}$ adalah jumlah variabel independen) diperoleh nilai dL sebesar 1.46 dan 
dU sebesar 1.63. Untuk nilai DW yang dihasilkan dari model regresi adalah 1.973. Karena nilai DW terletak antara dU yaitu sebesar 1.63 dan (4-dU) yaitu sebesar 2.37, maka hipotesis nol diterima, yang berarti tidak ada autokorelasi.

\section{Hasil dan Pembahasan}

\section{Pengujian Hipotesis Secara Parsial (Uji t)}

Pengujian hipotesis parsial dilakukan dengan membandingkan nilai sig pada tabel coefficient output SPSS atau $t_{\text {tabel }}<t_{\text {hitung, }}$ jika probabilitas $0,05<$ nilai probabilitas sig pada tabel coefficient, maka Ho,diterima dan $\mathrm{Ha}_{1}$ ditolak atau sebaliknya jika nilai probabilitas $0,05>$ nilai probabilitas sig pada tabel coefficient output SPSS atau $\mathrm{t}_{\text {tabel }}>\mathrm{t}_{\text {hitung, }}$, maka Ho,ditolak dan $\mathrm{Ha}_{1}$ diterima. $\mathrm{T}_{\text {tabel }}$ dapat dilihat pada tabel statistik pada signifikansi $0.05 / 2=0.025$ dengan derajat kebebasan $(\mathrm{df})=50-\mathrm{k}-1=50-2-1=$ 47 yaitu sebesar 2.011. Hasil coefficient output SPSS adalah sebagai beikut:

\section{Coefficients $^{\mathrm{a}}$}

\begin{tabular}{|l|r|r|r|r|r|}
\hline & \multicolumn{2}{|c|}{$\begin{array}{c}\text { Unstandardized } \\
\text { Coefficients }\end{array}$} & $\begin{array}{c}\text { Standardized } \\
\text { Coefficients }\end{array}$ & & \\
\cline { 2 - 5 } Model & \multicolumn{1}{|c|}{$B$} & \multicolumn{1}{c|}{$\begin{array}{c}\text { Std. } \\
\text { Error }\end{array}$} & Beta & t & \multirow{2}{*}{ Sig. } \\
\hline 1 (Constant) & 140.958 & 48.930 & & 2.881 & .006 \\
X1_Supervisi & .720 & .159 & .560 & 4.522 & .000 \\
X2_Pelatihan & .570 & .226 & .312 & 2.518 & .015 \\
\hline
\end{tabular}

Dependent Variable: profesionalisme

Berdasarkan hasil coefficient output SPSS, selanjutnya dilakukan pengujian hipotesis sebagai berikut:

\section{Pengaruh Tindakan Supervisi Terhadap Profesionalisme Auditor Pemula}

Hasil penelitian menunjukkan bahwa nilai t hitung lebih besar dari t tabel $(4,522>2,011)$ dan nilai probabilitas sig lebih besar dari $0.05(0.05>0.00)$ artinya hipotesis Ha diterima dan Ho ditolak. Dengan demikian dapat disimpulkan bahwa tindakan superivisi berpengaruh terhadap profesionalisme auditor pemula. Pengaruh tersebut ditunjukkan jika tindakan supervisi tinggi dilakukan, maka profesionalisme auditor pemula juga tinggi. Sebaliknya, apabila tindakan supervisi rendah, maka profesionalisme auditor pemula juga rendah. Tindakan supervisi mencakup sikap kepemimpinan dan mentoring yang baik, menciptakan kondisi kerja yang kondusif, serta penugasan yang menantang dan menstimulir terselesainya suatu tugas, maka profesionalisme auditor pemula akan dapat terbentuk. Hal penilitian ini konsisten 
dengan penelitian yang dilakukan oleh Nensitriyas Sulandari dimana aspek tindakan supervisi berpengaruh signifikan terhadap profesionalisme auditor Pemula

\section{Pelatihan Auditor (X2) Terhadap Profesionalisme Auditor Pemula (Y)}

Hasil penelitian menunjukkan bahawa nilai t hitung lebih besar dari t tabel $(2,518>2,011)$ dan nilai probabilitas sig lebih besar dari $0.05(0.05>0.015)$, artinya hipoteis Ha diterima dan Ho ditolak. Dengan demikian dapat disimpulkan bahwa pelatihan auditor berpengaruh terhadap profesionalisme auditor pemula, artinya jika pelatihan auditor tinggi, maka profesionalisme auditor juga tinggi. Sebaliknya, apabila pelatihan auditor rendah, maka profesionalisme auditor pemula juga rendah. Pelatihan auditor ini dapat berupa seminar, symposium, lokakarya pelatihan auditor sendiri, dan kegiatan penunjang keterampilan lainnya yang berkaitan dengan pengetahuan mengenai kekeliruan. Dengan mengikuti kegiatan pelatihan diatas Profesionalisme Auditor Pemula akan terbentuk. Hasil penelitian ini konsisten dengan penelitian yang dilakukan oleh Nensitriyas Sulandari dimana aspek Pelatihan Auditor berpengaruh signifikan terhadap Profesionalisme Auditor Pemula.

Selanjutnya untuk mengetahui besarnya pengaruh tindakan supervisi dan pelatihan auditor terhadap profesionalisme auditor pemula secara parsial dilakukan dengan model persamaan regresi berganda dengan hasil sebagai berikut:

$$
\begin{aligned}
& \mathrm{Y}=\alpha+\beta 1 \mathrm{X} 1+\beta 2 \mathrm{X} 2+\varepsilon \text { atau } \\
& \mathrm{Y}=140.958+0.560 \mathrm{X} 1+0.312 \mathrm{X} 2+\varepsilon
\end{aligned}
$$

a. Konstanta sebesar 140.958 artinya, jika tindakan supervisi (X1) dan pelatihan auditor (X2) nilainya 0 maka profesionalisme auditor pemula (Y) sebesar 140.958.

b. Koefisiensi regresi variabel tindakan supervisi (X1) sebesar 0.560, artinya bahwa setiap peningkatan tindakan supervisi sebesar 1, maka profesionalisme auditor pemula bernilai tetap (konstan).

c. Nilai koefisien regresi variabel pelatihan auditor bernilai positif, yaitu sebesar 0.312 ini dapat diartikan bahwa setiap peningkatan pelatihan auditor sebesar 1, maka profesionalisme auditor pemula juga akan meningkat sebesar 0.312.

\section{Pengujian Hipotesis Secara Simultan (Uji F)}

Pengujian Hipotesis Secara Simultan (Uji F) dilakukan dengan cara membandingkan $F_{\text {hitung }}>F_{\text {tabel }}$ dimana $F_{\text {hitung }}$ diperoleh dari hasil Output SPSS dalam Anova, sedangkan $\mathrm{F}_{\text {tabel }}$ diperoleh dari tabel df penyebut $=\mathrm{n}-\mathrm{k}-1=50-2-1=47$, df pembilang $=\mathrm{k}=2$, yaitu $\mathrm{F}_{\text {tabel }}=3.23$. Hasil Output SPSS untuk $F_{\text {hitung }}$ di sajikan pada berikut :

ANOVA ${ }^{b}$

\begin{tabular}{|l|c|c|c|c|c|}
\hline Model & $\begin{array}{c}\text { Sum of } \\
\text { Squares }\end{array}$ & df & $\begin{array}{c}\text { Mean } \\
\text { Square }\end{array}$ & F & Sig. \\
\hline
\end{tabular}




\begin{tabular}{|ll|c|c|c|c|c|}
1 & Regression & 251502.958 & 2 & 125751.479 & 46.707 & $.000^{\mathrm{a}}$ \\
& Residual & 126539.753 & 47 & 2692.335 & & \\
Total & 378042.711 & 49 & & & \\
\hline
\end{tabular}

a. Predictors: (Constant), supervisi,pelatihan

b. Dependent Variable: profesionalisme

Hasil uji F menunjukkan bahwa nilai F hitung lebih besar dari F tabel (46,707 > $3,2)$, artinya hipotesis Ha diterima dan Ho ditolak. Dengan demikian dapat disimpulkan bahwa tindakan supervisi dan pelatihan auditor berpengaruh terhadap profesionalisme auditor pemula. Tindakan supervisi dan pelatihan auditor tinggi, maka profesionalisme auditor pemula juga tinggi. Sebaliknya, jika tindakan supervisi dan pelatihan auditor rendah, maka profesionalisme auditor juga rendah. Profesionalisme auditor pemula dapat tercermin dengan pengabdian pada profesi, kewajiban sosial, kemandirian, keyakinan terhadap profesi, dan hubungan dengan sesama profesi.

Selanjutnya untuk mengetahui besarnya pengaruh tindakan supervisi dan pelatihan auditor terhadap profesionalisme auditor pemula secara simultan disajikan pada output SPSS sebagai berikut :

Model Summary

\begin{tabular}{|c|c|c|c|c|c|}
\hline Model & $\mathrm{R}$ & $\begin{array}{c}\mathrm{R} \\
\text { Square }\end{array}$ & $\begin{array}{c}\text { Adjusted } \\
\text { R Square }\end{array}$ & $\begin{array}{c}\text { Std. Error } \\
\text { of the } \\
\text { Estimate }\end{array}$ & $\begin{array}{c}\text { Durbin- } \\
\text { Watson }\end{array}$ \\
\hline 1 & $.816^{\mathrm{a}}$ & .665 & .651 & 51.88772 & 1.973 \\
\hline
\end{tabular}

a. Predictors: (Constant), supervisi, pelatihan

b. Dependent Variable: profesionalisme

\section{Sumber : Output SPSS}

Dari tabel di atas dapat diketahui pengaruhtindakan supervisi dan pelatihan auditor berpengaruh signifikan terhadap profesionalisme auditor pemula sebesar66.50\%, sedangkan sisanya sebesar $33.50 \%$ dipengaruhi oleh faktor lain di luar model penelitian.

\section{KESIMPULAN}

Berdasarkan hasil penelitian dan pembahasan, maka dapat di simpulkan sebagai berikut: 
1. Tindakan supervisi berpengaruh positif terhadap profesionalisme Auditor Pemula, hal ini dapat dilihat bahwa nilai $t$ hitung sebesar 4,522 > dari nilai nilai t tabel sebesar 2,011 (4,522> 2,011) dan nilai probabilitas sig lebih besar dari 0.05 (0.05 $>0.00$ ).

2. Pelatihan auditor berpengaruh positif terhadap profesionalisme auditor pemula, hal ini dapat dilihat nilai $t$ hitung sebesar 2,518 > dari nilai t tabel sebesar 2,011 $(2,518>2,011)$ dan nilai probabilitas sig lebih besar dari $0.05(0.05>0.015)$

3. Tindakan supervisi dan pelatihan auditor berpengaruh positif terhadap profesionalisme auditor pemula, hal ini dapat dilihat bahwa nilai $\mathrm{F}$ hitung sebesar 46,707 > dari nilai $F$ tabel sebesar 3,23 (46,707 > 3,23). Besarnya pengaruh

4. tindakan supervisi dan pelatihan auditor terhadap profesionalisme auditor pemula adalah 0,665 (66,50\%), sisanya sebesar $23.50 \%$ dipengaruhi oleh faktor lain diluar model penelitian.

\section{DAFTAR PUSTAKA}

Agoes, Sukrisno. 2004. “Auditing (Pemeriksaan Akuntan) oleh Kantor Akuntan Publik Jilid 1”. Edisi 3. Lembaga Penerbit Fakultas Ekonomi Universitas Indonesia. Jakarta.

Arens, Alvin \& Beasley. 2008. "Auditing Dan Jasa Assurance: Pendekatan Terintegrasi." Jilid 1. Edisi 12. Jakarta: Erlangga.

Ghozali, Imam. 2005. Aplikasi Analisis Multivariate Dengan Program SPSS. Edisi 3. Badan Penerbit Universitas Diponegoro. Semarang.

Ikatan Akuntan Indonesia. 2001. Standar Profesional Akuntan Publik. Jakarta: Salemba Empat.

Joko Sulistyo. 2002. 6 Hari Jago SPSS 17. Cakrawala. Yogyakarta.

Kusuma, Novanda Friska Bayu Aji. 2012. "Pengaruh Profesionalisme Auditor, Etika Profesi dan Pengalaman Auditor terhadap Pertimbangan Tingkat Materialitas". Fakultas Ekonomi Universitas Negeri Yogyakarta. Yogyakarta.

Malayu S.P. Hasibuan. 2006. Manajemen Sumber Daya Manusia. Jakarta.: Bumi Aksara.

Malik, Reza Setiawan Syah. 2010. Pengaruh Profesionalisme dan Etika Profesi Terhadap Pertimbangan Tingkat Materialitas dalam Pemeriksaan Laporan Keuangan. Fakultas Ekonomi Universitas Islam Negeri. Jakarta.

Mangkunegara, Anwar Prabu. 2013. Manajemen Sumber Daya Manusia Perusahaan. PT. Remaja Rosdakarya. Bandung

Mulyadi. 2002. Auditing Buku Satu. Jakarta: Salemba Empat 
Nurrahman, Myrna dan Nur Indriyanto, "Tindakan Supervisi dan Kepuasan Kerja Akuntan Pemula di Kantor Akuntan Publik". Jurnal Riset Akuntansi Indonesia. Vol. 3 No. 1 Januari 2000.

Santoso, Singgih. 2000. “SPSS Versi 10.0”, PT. Elex Media Komputindo, Gramedia, Jakarta.

Sekaran, Uma. 2006. Metodologi Penelitian Untuk Bisnis. Jakarta: Salemba Empat.

Sri Yuliawati, 2009 Metodologi Penelitian, STKIP Purnamam Cetakan Pertama, Jakarta

Soewadji, Jusuf. 2012. Pengantar Metodologi Penelitian. Jakarta: Mitra Wacana Media.

Sugiyono. 2008. Metode Penelitian Bisnis. Bandung: CV. Alfabeta.

Sulandari, Nensitriyas. 2011. Pengaruh Tindakan Supervisi dan Pelatihan Auditor Terhadap Profesionalisme Auditor Pemula. Jurnal Akuntansi. Yogyakarta. 
